\title{
ANALISIS KOEFISIEN ATTENUASI BAHAN PLASTIK MENGGUNAKAN SENSOR CAHAYA SMARTPHONE
}

\author{
Adi Pramuda ${ }^{1}$, Soka Hadiati ${ }^{2}$, Mislan Sasono ${ }^{3}$ \\ ${ }^{1,2}$ Program Studi Pendidikan Fisika, FMIPA, IKIP-PGRI Pontianak \\ ${ }^{3}$ Program Studi Pendidikan Fisika, FMIPA, IKIP PGRI MADIUN \\ Email : ${ }^{1}$ adipramuda@gmail.com; ${ }^{2}$ sukahaiati@ymail.com; ${ }^{3}$ mislan@ikipprgimadiun.ac.id
}

\begin{abstract}
Abstrak
Untuk menekan mainstream yang negatif terhadap penggunaan smartphone, salah satunya adalah dengan kajian yang inovatif dan menarik untuk memanfaatkan smartphone sebagai media bantu pembelajaran, eksperimen sains dan fisika. Pada penelitian ini dikaji karakteristik koefisien attenuasi bahan plastik menggunakan sensor cahaya pada smartphone secara sederhana. Hasil penelitian menunjukkan filter bahan plastik berwarna kuning dan biru yang digunakan didapati memiliki nilai $R^{2}$ yang secara teknis cukup relevan untuk menunjukkan karakteristik linier attenuation coefficient. Sedangkan tren dari $\mu$ (attenuation coefficient) filter bahan plastik berwarna merah cenderung sesuai untuk tren polinomial dengan nilai $R^{2}$ yang jauh lebih baik dari pada tren linier. Pemilihan filter yang tepat menjadi hal yang penting untuk mempermudah pembelajaran, selain sebenarnya tersembunyi berbagai konsep fisika yang menarik bila didapatkan hasil yang mungkin berbeda dengan teori dasarnya. Penggunaan smartphone untuk eksperimentasi sederhana sesuai dengan langkah yang dipaparkan dalam penelitian ini diharapkan dapat meningkatkan motivasi siswa untuk akrab dengan persamaan Lambert-Beer, selain itu, dapat menjadi batu loncatan untuk mempelajari peristiwa absorbsi serta transmisi cahaya oleh bahan.
\end{abstract}

Kata Kunci: Koefisien Attenuasi; Bahan Plastik; Sensor Cahaya; Smartphone.

\section{Pendahuluan}

Hasil dari perkembangan teknologi pada masa kini erat kaitannya dengan semakin canggih dan semakin populernya penggunaan smartphone di masyarakat. Dunia pendidikan bahkan harus memikirkan cara untuk merespon dengan baik perkembangan teknologi yang amat pesat ini. Memang sangat disadari bahwa penggunaan teknologi smatphone memiliki dampak positif dan negatif. Untuk menekan mainstream yang negatif salah satunya adalah dengan memanfaatkan smartphone sebagai alat untuk pengambilan data eksperimen sains, menggunakan basis sensor yang dimilikinya ${ }^{1}$. Sensor pada smartphone sangat bermanfaat di bidang ilmu fisika, terutama untuk mengenalkan konsep dasar dengan lebih responsif dan realistis. Tiga sensor utama yang seakan-akan menggantikan fungsi mata; telinga; dan tangan adalah GPS, kamera, dan sensor cahaya; speaker dan microphone yang terintegrasi dengan spectrum analyzer; serta smart accelerometer dan sensor magnetik ${ }^{2}$. Melalui tiga kategori sensor utama ini tidak sedikit "smart experiment" yang telah dikaji dan telah dipublikasikan yang bermanfaat untuk pendidikan fisika, namun demikian jumlah ini masih sangat sedikit bila dibandingkan dengan konsep fisika yang sangat komprehensif, dan potensi pemanfaatan smartphone yang sangat luas di bidang pendidikan ${ }^{3}$.

Masih diperlukan berbagai kajian yang inovatif dan menarik untuk memanfaatkan smartphone sebagai media bantu pembelajaran, eksperimen sains dan fisika. Berkaitan dengan penggunaan kamera dan sensor cahaya, beberapa konsep fisika yang sudah dikaji adalah berkaitan dengan difraksi, radiasi inframerah ${ }^{3}$, serta pengaruh konsentrasi suatu zat terhadap warna yang ditimbulkan ${ }^{2}$. Hal ini tentunya membuka peluang baru untuk kajian terhadap persamaan Lambert - Beer yang bermanfaat untuk kajian yang lebih mendalam berkaitan optik nonlinier. Pada penelitian ini 
dikaji karakteristik koefisien attenuasi bahan plastik menggunakan sensor cahaya pada smartphone secara sederhana.

\section{Metode Penelitian}

Berdasarkan eksperimentasi berkaitan persamaan Lambert - Beer yang umum dilakukan di fisika dasar berkenaan optik, maka langkah pertama adalah menyiapkan sumber cahaya, bahan, dan detektor. Sumber cahaya yang digunakan dan detektornya cukup dengan menggunakan aplikasi senter dan luxmeter yang ada pada smartphone. Adapun bahan yang digunakan untuk menunjukkan kemudahan eksperimentasi ini adalah plastik berwarna yang sering digunakan sebagai sampul buku. Bahan ini cukup murah dan mudah untuk didapatkan. Langkah kedua adalah melakukan pengukuran dengan empat kondisi yang dapat dilustrasikan pada Gambar 1 sampai Gambar 4.

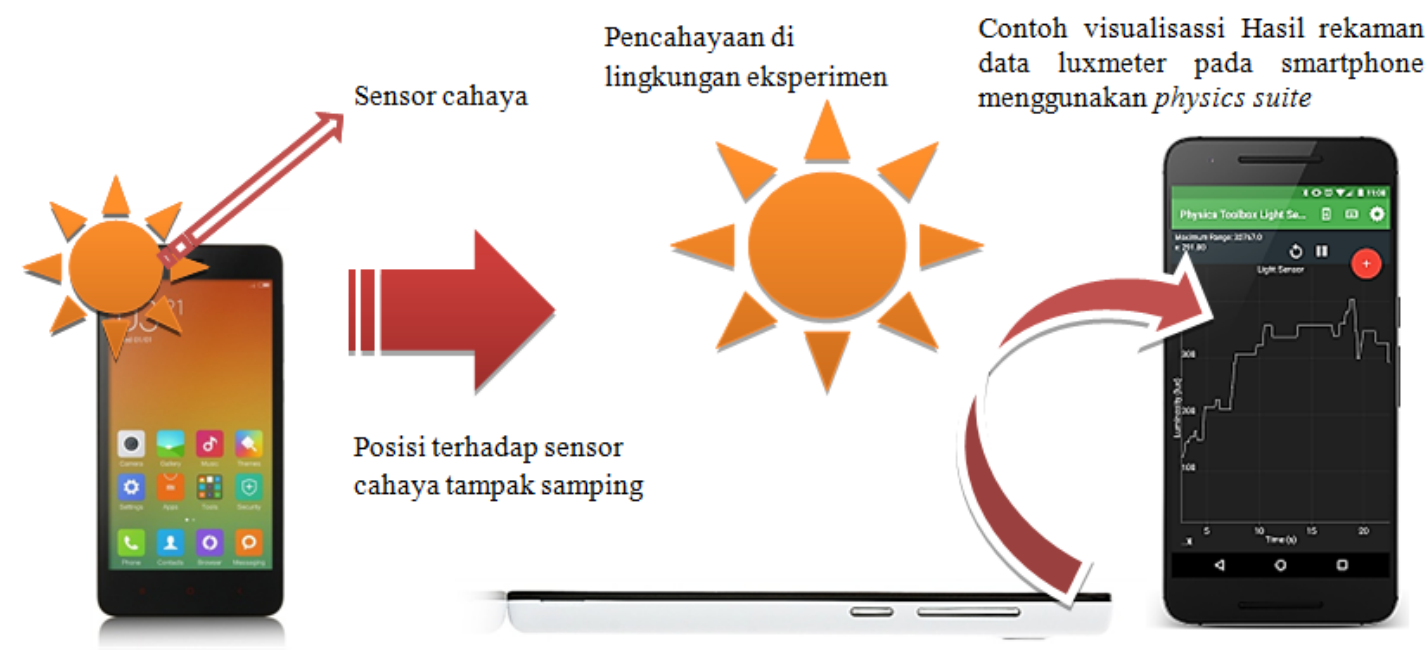

Gambar 1. Pengukuran intensitas pencahayaan di lingkungan eksperimen.
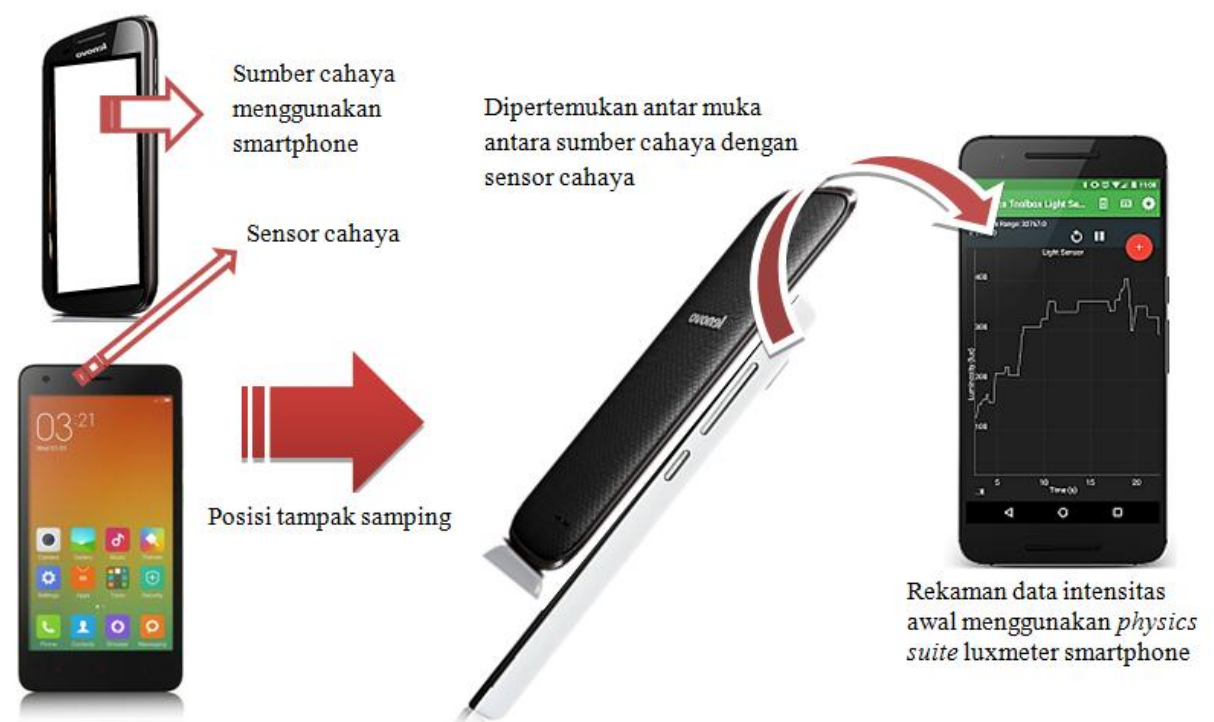

Gambar 2. Pengukuran intensitas awal sumber cahaya yang digunakan. 

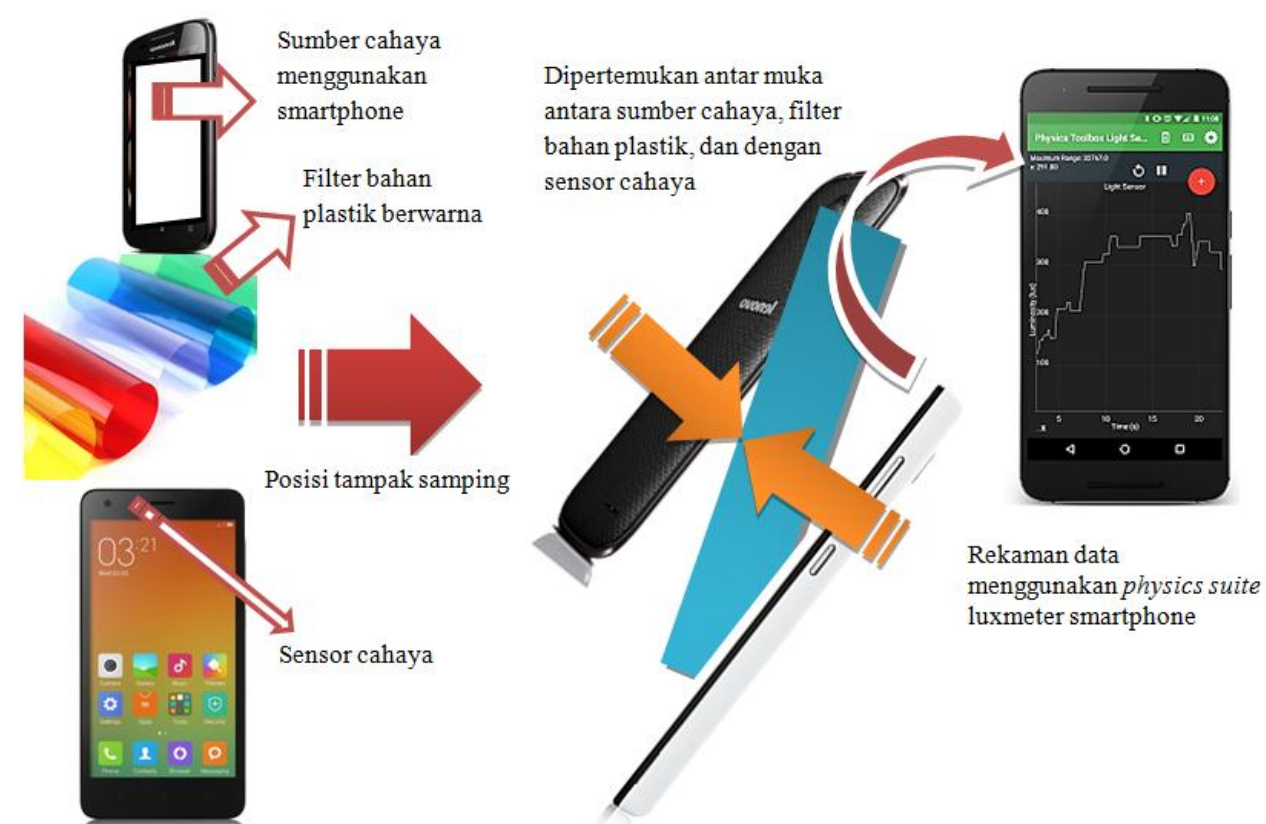

Gambar 3. Pengukuran intensitas sumber cahaya yang diterima detektor setelah melalui filter atau penghalang bahan plastik dengan warna tertentu.
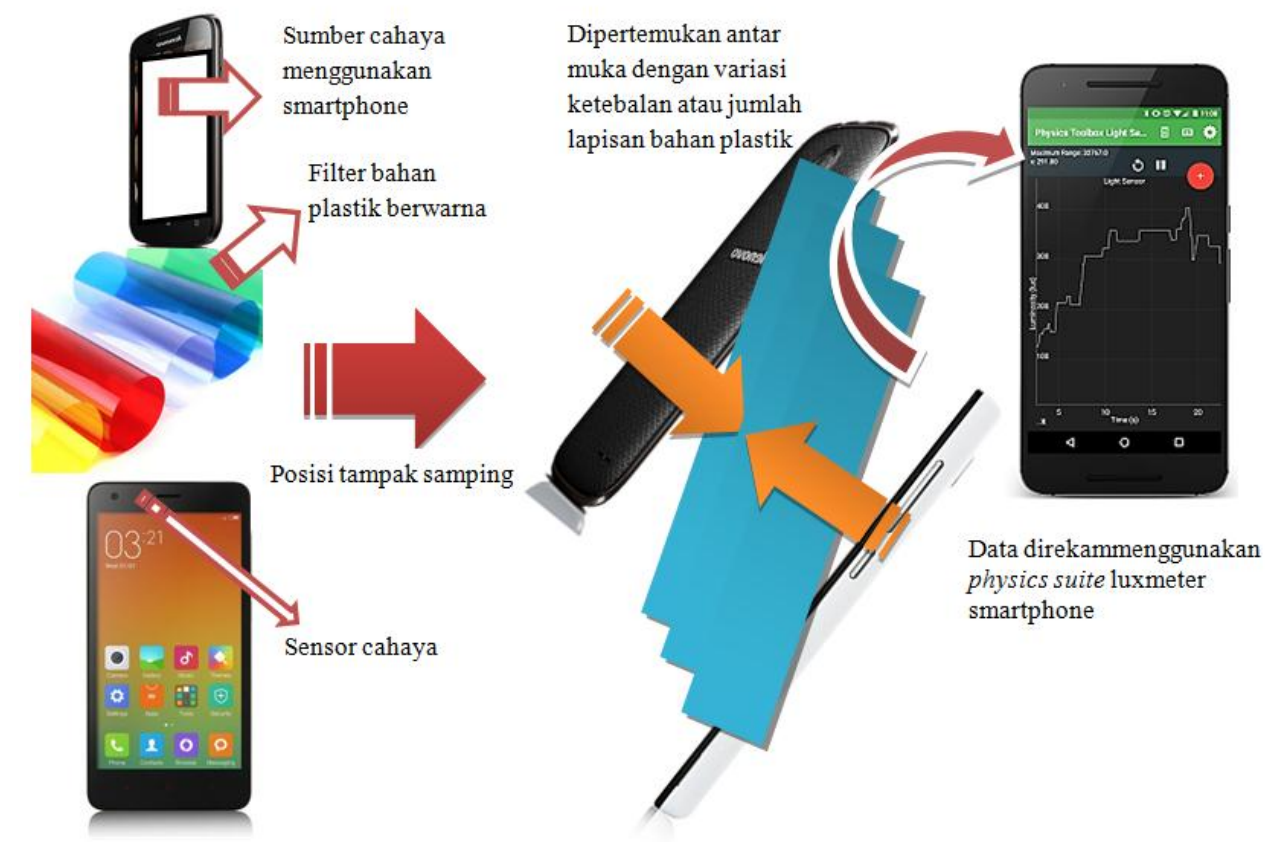

Gambar 4. Pengukuran intensitas sumber cahaya yang diterima detektor setelah melalui filter atau penghalang bahan plastik dengan warna tertentu dan ketebalan tertentu.

Langkah ketiga adalah membuat plot Pengukuran intensitas sumber cahaya yang diterima detektor setelah melalui filter atau penghalang bahan plastik dengan warna tertentu dan ketebalan tertentu. Langkah yang terakhir adalah melakukan fitting untuk memperoleh persamaan koefisien attenuasi dan analisis. Adapun pada kajian ini persamaan Lambert - Beer yang menjelaskan radiasi sinar atau cahaya yang menembus suatu bahan disajikan pada persamaan 1 . 
Hal yang perlu direkam adalah intensitas pencahayaan di lingkungan eksperimen, intensitas awal sumber cahaya yang digunakan, intensitas sumber cahaya yang diterima detektor setelah melalui filter atau penghalang bahan plastik dengan warna tertentu, intensitas sumber cahaya yang diterima detektor setelah melalui filter atau penghalang bahan plastik dengan warna tertentu dan ketebalan tertentu. Ketebalan bahan secara teknis pada setiap variasi lapisan plastik sengaja tidak diukur karena asumsi homogenitas bahan plastik, dan untuk menunjukkan bahwa pengukuran hal tersebut dapat dilakukan namun tidak dalam konteks yang dimaksudkan pada kaijan ini. Digunakan variasi ketebalan lapisan dari satu sampai enam lapis. Adapun warna filter yang digunakan adalah merah, kuning, dan biru.

$$
I=I_{0} e^{-\mu x}
$$

Dimana $I_{0}$ adalah Intensias awal dan $I$ adalah intensitas radiasi cahaya yang ditransmisikan, $x$ adalah ketebalan bahan filter and $\mu$ adalah linear attenuation coefficient ${ }^{4}$.

\section{Hasil Dan Pembahasan}

Apabila data sesuai prosedur pada Gambar 1 sampai Gambar 3 divisualisasikan secara keseluruhan dengan warna filter yang digunakan adalah merah, kuning, dan biru, maka contoh hasilnya disajikan pada Gambar 5 .

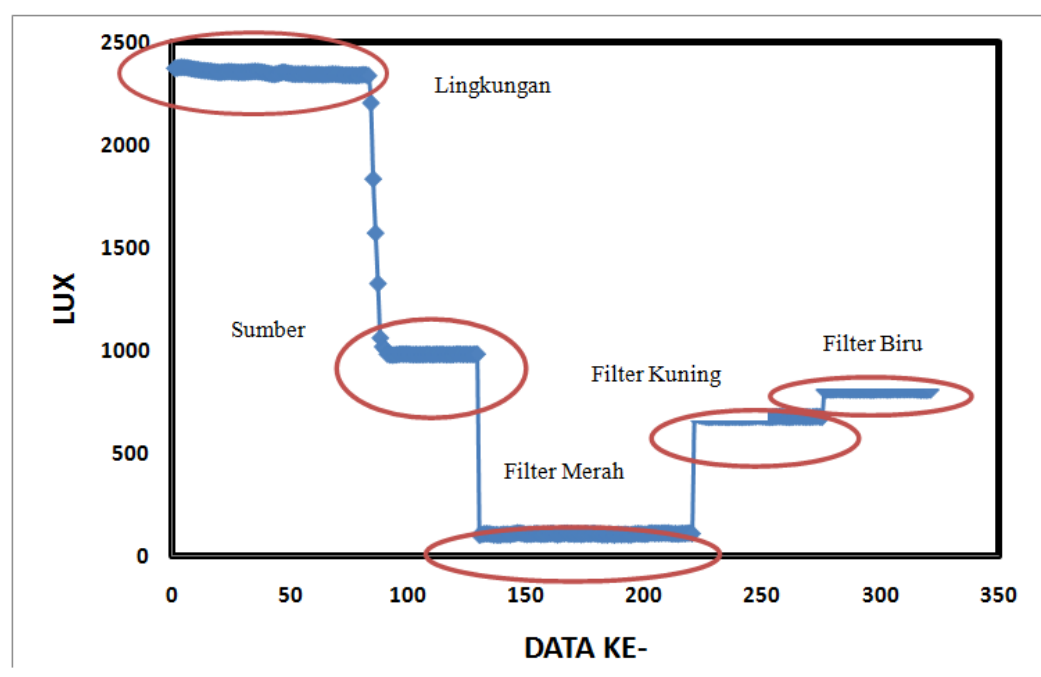

Gambar 5. Hasil pengukuran intensitas sumber cahaya yang diterima detektor pada lingkungan, intensitas sumber cahaya awal yang digunakan, dan intensitas cahaya setelah melalui filter atau penghalang bahan plastik satu lapis (secara keseluruhan dengan warna filter yang digunakan adalah merah, kuning, dan biru).

Pada penelitian ini disebabkan bidang sumber cahaya dapat melingkupi permukaan sensor cahaya secara optimal, maka setelah dipertemukan antar muka pengaruh pembacaan luxmeter dominan hanya disebabkan oleh sumber cahaya. Pada eksperimen didapati sekalipun perangkat dibawa ke lngkungan dengan intensitas pencahayaan yang lebih tinggi atau lebih rendah namun dengan konfigurasi sumber cahaya dan filter yang tetap, tidak didapatkan pengaruh yang signifikan.

Untuk selanjutnya pada penelitian ini mengambil setting pada lingkungan dengan intensitas pencahayaan di atas 2000 lux dan intensitas sumber cahaya awal relatif tetap dengan nilai reratanya, yaitu 990 lux. Berdasarkan Gambar 5 didapati bahwa menggunakan filter satu lapis warna merah, intensitas yang terukur lebih rendah dari warna kuning dan biru, dengan warna biru memiliki nilai pembacaan intensitas yang paling tinggi. Nilai rerata intensitas cahaya setelah melalui filter atau penghalang bahan plastik dari satu sampai enam lapis (warna filter yang digunakan adalah merah, kuning, dan biru) hasil pengkuran menggunakan physics suite luxmeter pada smartphone selengkapnya disajikan pada Tabel 1. Apabila nilai rerata tersebut jika di plot, maka didapatkan grafik 
JPFK, Vol. 2 No. 2, September 2016, hal 70 -77

http://e-journal.ikippgrimadiun.ac.id/index.php/JPFK

seperti disajikan pada Gambar 6, Gambar 7, dan Gambar 8.

Tabel 1. Rerata intensitas cahaya setelah melalui filter atau penghalang bahan plastik dari satu sampai enam lapis (warna filter yang digunakan adalah merah, kuning, dan biru).

\begin{tabular}{lrrrrrr}
\hline \multirow{2}{*}{ WARNA FILTER } & \multicolumn{1}{c}{ RERATA INTENSITAS CAHAYA SETELAH MELALUI FILTER (LUX) } \\
\cline { 2 - 7 } & 1 LAPIS & 2 LAPIS & 3 LAPIS & 4 LAPIS & 5 LAPIS & 6 LAPIS \\
\hline MERAH & 107 & 38 & 30 & 28 & 26 & 24 \\
\hline KUNING & 677 & 539 & 449 & 375 & 324 & 268 \\
\hline BIRU & 809 & 664 & 538 & 451 & 395 & 354 \\
\hline
\end{tabular}

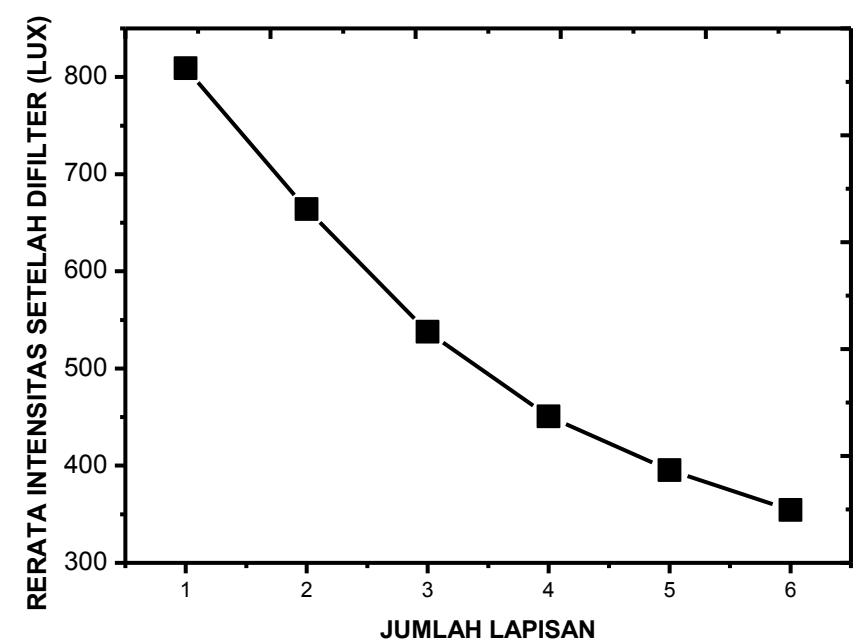

Gambar 6. Grafik rerata intensitas cahaya setelah melalui filter terhadap ketebalan lapisan filter bahan plastik (warna merah).

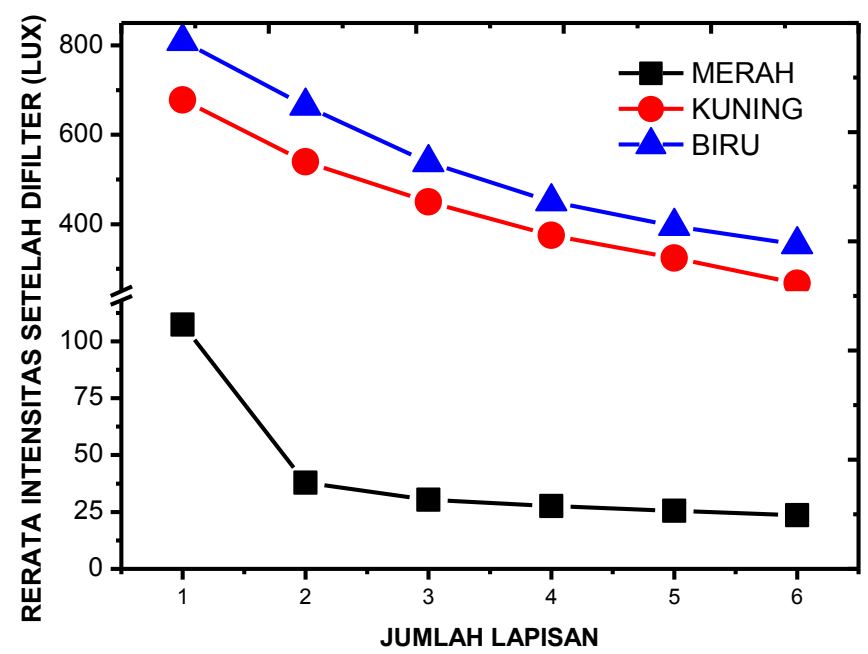

Gambar 7. Grafik rerata intensitas cahaya setelah melalui filter terhadap ketebalan lapisan filter bahan plastik (warna merah, kuning, dan biru). 


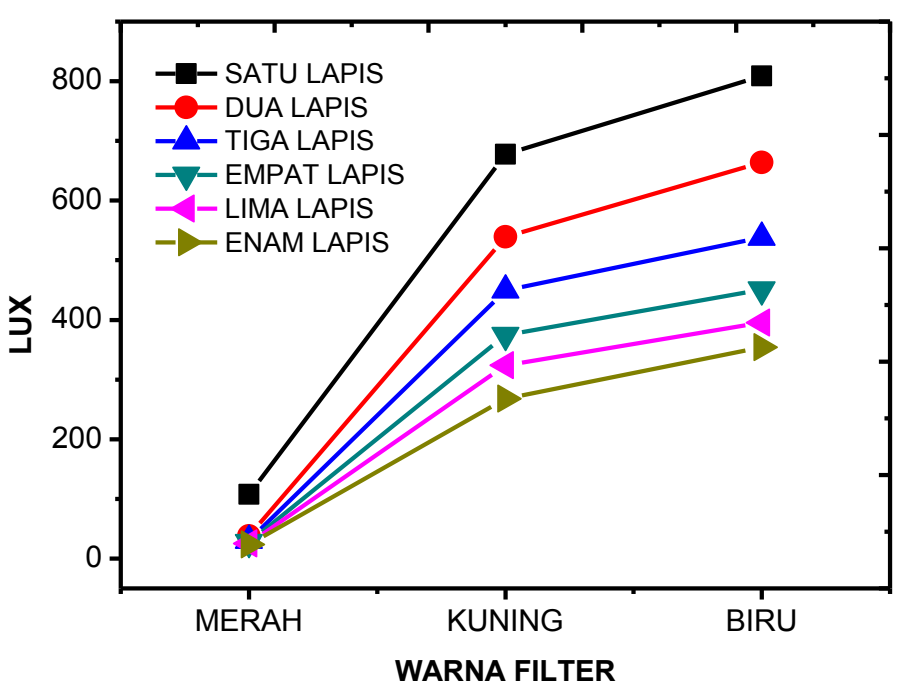

Gambar 8. Grafik rerata intensitas cahaya setelah melalui filter terhadap warna filter bahan plastik (dari satu sampai enam lapis).

Gambar 6, Gambar 7, dan Gambar 8 menunjukkan bahwa intensitas cahaya setelah melalui bahan berubah seiring perubahan ketebalan dan warna bahan filter yang digunakan. Semakin tebal bahan yang ditandai dengan semakin banyaknya lapisan filter yang digunakan, maka daya tembus cahaya makin lemah. Adapun peluruhannya dapat dilakukan fitting mengikuti tren eksponensial. Warna merah lebih sulit untuk ditembus bila dibandingkan dengan warna kuning dan biru, sedangkan warna biru paling mudah ditembus oleh radiasi cahaya. Untuk mencari nilai dari $\mu x$ dan karakteristik $\mu$ (attenuation coefficient) dibuat plot antara nilai $\ln I / I_{0}$ terhadap ketebalan lapisan filter bahan plastik. Adapun grafik yang dihasilkan disajikan pada Gambar 9. Hasil fitting linier, polinomial, dan nilai $R$ square disajikan pada Tabel 2.

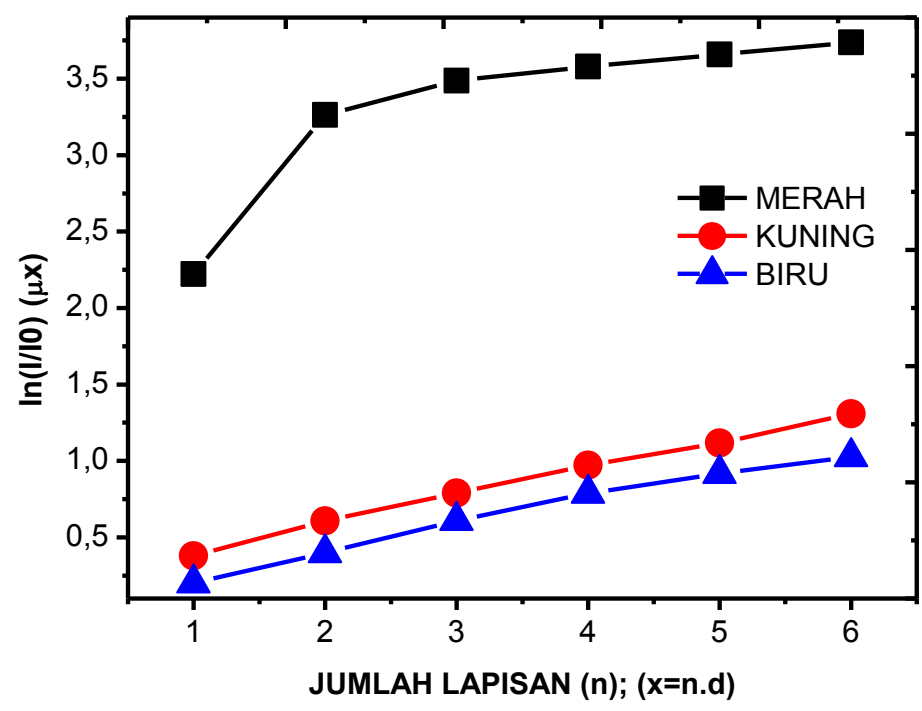

Gambar 9. Nilai $\mu x$ dan karakteristik $\mu$ (attenuation coefficient) filter bahan plastic (dari satu sampai enam lapis warna merah, kuning, dan biru).

Berdasarkan Gambar 9 dan Tabel 2, tampak bahwa $\mu$ (attenuation coefficient) bahan plastik yang digunakan bervariasi untuk warna yang berbeda hal ini konsisten dengan
Gambar 6, Gambar 7, dan Gambar 8 yang menunjukkan bahwa intensitas cahaya setelah melalui bahan berubah seiring perubahan warna bahan filter yang digunakan. Hubungan 
ini dalam bentuk persamaan sesuai dengan persamaan 2 .

$$
I(\lambda)=I_{0}(\lambda) e^{-\mu(\lambda) x}
$$

Apabila ketebalan dari filter pada tiap lapisan homogen dan konstan, sisi yang menarik adalah tren dari $\mu$ (attenuation coefficient) filter bahan plastik berwarna merah cenderung sesuai untuk tren polinomial dengan nilai $R^{2}$ yang jauh lebih baik dari pada tren linier. Tentunya hal ini berdampak teknis kurang baik jika digunakan untuk pembelajaran. Kondisi ini juga menunjukkan bahwa karakteristik konsentrasi molekul yang digambarkan dengan kepekatan dye berbeda dengan dua warna lainnya. Bisa dikatakan bahwa plastik warna merah masuk dalam kategori kepekatan warna yang berbeda dengan dua warna lainnya, filter bahan plastik warna kuning dan biru cenderung masuk dalam kategori yang sama. Temuan ini sekaligus merupakan koreksi bahwa dimungkinkan ada keterkaitan antara warna dengan konsentrasi molekul, maupun parameter lain seperti tingkat keasaman ${ }^{2}$, namun hubungannya tidaklah selalu dapat dipastikan linier, misalnya dimungkinkan koreksi karena adanya hamburan. Filter bahan plastik berwarna kuning dan biru memiliki nilai $R^{2}$ yang sedikit lebih baik dari pada tren liniernya dan bila dipaksakan mengikuti tren linier pun masih cukup relevan untuk menunjukkan karakteristik linier attenuation coefficient.

Penggunaan smartphone untuk eksperimentasi sederhana sesuai dengan langkah yang telah dipaparkan diharapkan dapat meningkatkan motivasi siswa untuk akrab dengan persamaan Lambert-Beer, selain itu, dapat menjadi batu loncatan untuk mempelajari peristiwa absorbsi serta transmisi cahaya oleh bahan.

Tabel 2. Nilai $\mu x$, hasil fitting linier, polinomial, dan nilai $R$ square filter bahan plastik (dari satu sampai enam lapis warna merah, kuning, dan biru).

\begin{tabular}{|c|c|c|c|}
\hline \multirow{2}{*}{$\mu x$} & \multicolumn{3}{|c|}{ WARNA FILTER } \\
\hline & MERAH & KUNING & BIRU \\
\hline \multicolumn{4}{|c|}{ Jumlah Lapisan } \\
\hline 1 & 2,221 & 0,379 & 0,201 \\
\hline 2 & 3,263 & 0,607 & 0,399 \\
\hline 3 & 3,486 & 0,789 & 0,610 \\
\hline 4 & 3,578 & 0,971 & 0,787 \\
\hline 5 & 3,659 & 1,117 & 0,918 \\
\hline 6 & 3,738 & 1,307 & 1,027 \\
\hline \multicolumn{4}{|l|}{ Linier Fit } \\
\hline persamaan & $y=0,8158 x$ & $y=0,2338 x$ & $y=0,1838 x$ \\
\hline$R^{2}$ & $-3,597$ & 0,894 & 0,9738 \\
\hline \multicolumn{4}{|c|}{ Polynomial Fit } \\
\hline persamaan & $y=-0,0962 x^{2}+0,9264 x+1,5402$ & $y=-0,006 x^{2}+0,2233 x+0,1708$ & $y=-0,0135 x^{2}+0,2623 x-0,0557$ \\
\hline$R^{2}$ & 0,9205 & 0,9985 & 0,9991 \\
\hline
\end{tabular}

\section{Kesimpulan}

Pada penelitian ini filter bahan plastik berwarna kuning dan biru yang digunakan didapati memiliki nilai $R^{2}$ yang secara teknis cukup relevan untuk menunjukkan karakteristik linier attenuation coefficient. Pemilihan filter yang tepat menjadi hal yang penting untuk mempermudah pembelajaran, selain sebenarnya tersembunyi berbagai konsep fisika yang menarik bila didapatkan hasil yang mungkin berbeda dengan teori dasarnya. Smartphone merupakan sarana yang cukup kompatibel untuk mempelajari berbagai konsep fisika dengan kemasan yang mudah dan lebih menarik. Oleh karena itu, masih dibutuhkan berbagai kajian serupa yang inovatif untuk lebih mengeksplorasinya. 


\section{Ucapan Terima Kasih}

The author acknowledges the support of IKIP-PGRI Pontianak Research Grant.

\section{Daftar Pustaka}

Rebecca Vieyra, Chrystian Vieyra, Philippe Jeanjacquot, Arturo Marti, dan Martín Monteiro. (2015). Turn Your Smartphone Into A Science Laboratory. The Science Teacher. Desember, pp: 32-40.

Science on Stage Europe. (2014). Smartphones in science teaching. Berlin, Germany: Science on Stage Deutschland e.V. http://bit.ly/1MXWXTH.

Jochen Kuhn dan Patrik Vogt. (2013). Applications and Examples of
Experiments with Mobile Phones and Smartphones in Physics Lessons. Frontiers in Sensors (FS). Volume 1 Issue 4, October, pp: 67-73.

D. Abayli dan N. Baydogan. (2015). The Characterization of the Irradiated $\mathrm{ZrO}_{2}$ Transparent Thin Films. Procedia Social and Behavioral Sciences. Vol. 195, pp: $2117-2121$. 